\title{
Developing Instructional Materials for Engineering Students: Focus on the Students' Communication Skills Needs
}

\author{
Dini Hadiani, Nia Nuryanti Permata \\ Politeknik Manufaktur Negeri Bandung \\ hadiani_dini@yahoo.com; nianp2000@yahoo.com
}

\begin{abstract}
Language and communication skills are recognized as important elements in the education of the modern engineer, including English for Specific Purposes (ESP). Consequently, there is a need for a valid and reliable form of teaching for engineering students. However, there has been an issue that many engineering students experience problems in communicating in English. This study seeks to identify the students' language needs especially to find out the specific instructional materials appropriate to them. The purpose of this study is to explore the communication skills needs of 40 engineering students, and to develop English for Specific Purpose materials based on their needs. Utilizing a qualitative method of inquiry, data were obtained through questionnaires and semi structured interviews. The findings revealed that the real communication skills needs of students, lecturers' view points on the expectation of ESP instructions, and the view point from the employers in engineering area. It was concluded that English language skills of speaking, reading, listening, and writing were important for engineering students and needed to be emphasized in the ESP course to satisfy their specific needs. Keywords: ESP, needs analysis, language needs, instructional materials
\end{abstract}

\section{INTRODUCTION}

Nowadays, communication skills play an important role in workplace. The effective communication skills are now required in every field of work, including engineering field. As a consequent, there is a clear necessity for effective English communication skills for engineers. A course in English for Specific Purposes (ESP) is considered a good way to enhance English language training and an engineering student's communication skills. As Maria (2009) states that the teaching of ESP for engineering students is designed to meet the specific needs of the learners and centered not only on the language (grammar, lexis, and register) but also on the skills and discourses. It indicates that the teaching of ESP for engineering students is not focused only to improve the students' English skill but also the most important thing is to improve their communication skill.

The concept of ESP achieved more in the education of engineering students is by focusing the learner's attention on particular terminology and communication skills required in the professional field. However, there are still many graduates' experience problems, despite graduating with excellent results. This is due to the problem of lack in communication skills, especially to communicate in English. Stevens (2005) stated that employers said a poor language skill was a barrier to being hired, "Many students come to me with poor English skills. I could not hire them because of our clients' perceptions". Stevens (2005) also added by saying that undergraduate students should be well aware that communication skills are in demand in the workplace. Thus, this study attempts to identify the students' communication skills needs which will be used for developing instructional materials appropriate to them.

\section{LITERATURE REVIEW}

Hutchinson and Waters (1987) defined ESP as "An approach to language teaching, in which all decisions as to content and methods are based on the learners' reasons for learning." It means that ESP is the teaching of English, which is based on the students' needs to learn English.

Richards and Schmidt in Richards (2001) said that ESP is "The role of English in a language course or program of instruction in which the contents and aims of the course are fixed by the specific needs of a particular group of learners." In other words, ESP is an English teaching given to special group of learners for special purposes, and the decision to choose the materials and teaching methods depend on the reasons why the learners learn English. In relation to those two descriptions about ESP, Mackay and Mountford in Robinson (1980) mentioned that the purposes of ESP are occupational requirement, vocational training, and academic or professional study. Referring all descriptions stated previously, it can be said that there is a common thing that is English for Specific Purposes is given to special learners with special needs, and that the contents (teaching materials) are developed based on the learners' needs or expectations.

According to Dudley-Evans and St. John (1998), the cornerstone of ESP is addressing the language which is required by learners as well as learning contexts of learners. As it is about specific learners, therefore, it must be tailored to the needs of these learners. This coordination is accomplished through what is called Needs Analysis (NA).

Needs analysis is "the process of determining the needs for which a learner or group of learners requires a language and arranging the needs according to priority." (Richards and Schmidt in Richards, 2001). It means that needs analysis plays an important role in developing materials that meet the learners' needs. Richards (2001) strongly stated that an important concern in ESP is needs analysis. 
Because needs have been defined from various perspectives, focusing on students' needs in designing a course is a demanding task. Hutchinson and Waters (1987) have classified needs into necessities, wants and lacks. In their classification, necessities are concerned with the demands of target situations, lacks refer to the gap between learner's existing language proficiency and the needed target situation language needs, and wants relate to learners' view on what their needs are.

In any ESP courses, expectations ought to be derived from their stakeholders. Connelly and Clandinin in Richards (2001) define stakeholders in ESP course are those who have a particular interest or involvement in the issues or programs that are being examined. Regarding the importance of expectations in ELT, Richterich and Chanceril in Richards (2001) suggested that learners, teachers, and employers could be involved in developing materials.

\section{METHODOLOGY}

The research approach used for this study was a qualitative case study design. This study was carried out at the undergraduate mechanical engineering study program at one polytechnic in Bandung. The research site has been chosen since as a member of the teaching staff with more than five years teaching experience, the researchers expected to get easy access to the research site, and hence, increases the feasibility of the study (Bogdan and Biklen, 1998). The participants of the study were forty students of Technical English subject.

The data were collected through the questionnaires and interview. The researcher was using the self-administered questionnaire as the research instrument. The questionnaire was designed to obtain the students' needs in communication skills. Varieties of question types were used in the questionnaire. They included the close-ended, open-ended, and ranking questions. The questions comprised of the students' target situations, the gap between learner's existing language proficiency and the needed target situation language needs, and the learners' view on what their communication skills in English needs are.

The other source of data was the interview with students, lecturers consisting of subject-specific lecturers and ESP practitioner, and employers. It was used to obtain more comprehensive data on the students' needs of communication skills which can be used for developing the instructional material appropriate to them.

As for data analysis, the students' questionnaries were tabulated and made into percentage. Then, the results were analyzed based on the theory of needs analysis proposed by Hutchinson and Waters (1987). In addition, data from interview was analyzed to justify data taken from the questionnaires.

\section{FINDINGS AND DISCUSSIONS}

The research results provided valuable insights on the students' communication skills needs. The findings are presented in two parts. Part one describes the results from questionnaires. Part 2 presents the data from the interviews.

\subsection{Findings from Questionnaires}

The findings are presented in the average percentages on the basis of questionnaires followed by discussions of each category. The results are elaborated below.

Table 1 Students' Rating on Their Current language Skill

\begin{tabular}{lllll}
\hline Skills & $\begin{array}{l}\text { Very } \\
\text { weak } \\
(\%)\end{array}$ & $\begin{array}{l}\text { Weak } \\
(\%)\end{array}$ & $\begin{array}{l}\text { Fair } \\
(\%)\end{array}$ & $\begin{array}{l}\text { Good } \\
(\%)\end{array}$ \\
\hline Listening & 10 & 35 & 40 & 15 \\
Reading & 0 & 12.5 & 57.5 & 30 \\
Speaking & 10 & 32.5 & 37.5 & 20 \\
Writing & 10 & 32.5 & 47.5 & 10 \\
Grammar & 8 & 40 & 42 & 10 \\
Vocabulary & 2.5 & 32.5 & 52.5 & 12.5 \\
Pronunciation & 8 & 30 & 42 & 20 \\
\hline
\end{tabular}

The students' rating on their current language is shown up in the table above. On the overall, $48 \%$ of the students have rated grammar skill as their weakest skill. The finding reveals that they have a great need to improve their grammar skill. It indicates that the students need the skills to support their communication skills. It is therefore recommended for teacher to give explicit teaching on grammar points that will be useful for them. This is in line with Riabtseva and Arestova's (2006) statement on the importance of the teaching of basic language concepts. Whereas, from the four language skills, Reading (57.5\%), Writing (47.5\%), Listening $(40 \%)$ and Speaking $(37.5 \%)$ are in "fair" category. This phenomenon might exist due to the process of learning ESP; their opinion was only focused on the two language skills. In the 'Vocabulary', the most majority students have "fair" category by $52.5 \%$ as well as the ability of "Pronunciation" by $(42 \%)$. It seems that the students do not see those aspects as problems for them.

Table 2 The Language Skills needed by engineers in their job

\begin{tabular}{llllll}
\hline Skills & 5 & 4 & 3 & 2 & 1 \\
\hline Reading & $75 \%$ & $20 \%$ & $5 \%$ & $0 \%$ & $0 \%$ \\
Writing & $65 \%$ & $15 \%$ & $10 \%$ & $10 \%$ & $0 \%$ \\
Speaking & $85 \%$ & $15 \%$ & $0 \%$ & $0 \%$ & $0 \%$ \\
Listening & $70 \%$ & $15 \%$ & $10 \%$ & $5 \%$ & $0 \%$ \\
\hline
\end{tabular}

Table 2 shows the interest percentage of students on language skills. The students wanted their ESP courses to focus on all the four language skills, because they believed they needed English in various situations in their future jobs. However, they expressed that their needs for all the four skills are not equal. Most of them are very interested in learning ESP Speaking activities (85\%), followed by Reading (75\%), Listening $(70 \%)$, and Writing $(65 \%)$. This finding concurs with the students' responses on their language learning objectives as in Table 3 whereby it is found that the students want to improve their speaking skill $(85 \%)$. This indicates 
that the students tend to improve their productive skill especially on how to deliver their ideas orally.

Table 3 The students' responses on their language learning objectives

\begin{tabular}{|c|c|c|}
\hline learning & Frequency & $\begin{array}{l}\text { Percentage } \\
(\%)\end{array}$ \\
\hline To improve my listening & 32 & 80 \\
\hline $\begin{array}{l}\text { To become more fluent } \\
\text { speaker }\end{array}$ & 34 & 85 \\
\hline $\begin{array}{l}\text { To improve my presentation } \\
\text { skill }\end{array}$ & 32 & 80 \\
\hline To improve my reading & 28 & 70 \\
\hline To improve my writing & 26 & 65 \\
\hline To expand my vocabulary & 30 & 75 \\
\hline $\begin{array}{l}\text { To improve my grammar } \\
\text { mastery }\end{array}$ & 25 & 62.5 \\
\hline $\begin{array}{ll}\text { To improve } & \text { my } \\
\text { pronunciation skill } & \end{array}$ & 30 & 75 \\
\hline
\end{tabular}

Concerning the topic of ESP, the students' responses can be seen in the following table.

Table 4 Students Responses on Topics for ESP

\begin{tabular}{|c|c|c|}
\hline Topics & Frequency & $\begin{array}{l}\text { Percentage } \\
(\%)\end{array}$ \\
\hline $\begin{array}{l}\text { Engineering materials \& } \\
\text { properties }\end{array}$ & 30 & 75 \\
\hline Shapes and dimensions & 33 & 82.5 \\
\hline Number and quantities & 25 & 62.5 \\
\hline Describing technical object & 32 & 80 \\
\hline Describing processes & 36 & 90 \\
\hline $\begin{array}{l}\text { Safety at work, hazards, } \\
\text { instructions }\end{array}$ & 23 & 57.5 \\
\hline $\begin{array}{l}\text { Places of work (workshop, } \\
\text { laboratories) }\end{array}$ & 30 & 75 \\
\hline
\end{tabular}

The students realized that the topics in ESP are very useful to science and technology. The results confirm that the targeted topics should be covered in the syllabus for Technical courses, according to Dudley-Evans (1998), one variable characteristic of ESP is to be related to or designed for specific disciplines.

Table 5 The Students Preferences of Activities in Learning English

\begin{tabular}{lll}
\hline Activities & Frequency & $\begin{array}{l}\text { Percentage } \\
(\%)\end{array}$ \\
\hline Individual & 12 & 30 \\
Group work & 32 & 80 \\
Whole class & 24 & 60 \\
Out of class work & 15 & 37.5 \\
Pair work & 25 & 62.5 \\
\hline
\end{tabular}

Table 5 shows that the most desirable activities performed by students in learning ESP are group work (80\%), pair work
(62.5\%) and whole class activities (60\%). Most students prefer not to do individuals activities in learning ESP.

In relation to the communication skills needs that are required by engineers, the results can be seen below.

Table 6 The Students' Responses on Communication Skills Needs

\begin{tabular}{lll}
\hline Communication Needs & Frequency & $\begin{array}{l}\text { Percentage } \\
(\%)\end{array}$ \\
\hline a. Listening & & \\
To lectures & 28 & 70 \\
To instructions & 27 & 67.5 \\
To presentations & 32 & 80 \\
To reports & 20 & 50 \\
To explanation of teacher & 26 & 65 \\
b. Speaking & & \\
Presentation & 34 & 85 \\
Explaining Process & 30 & 75 \\
Describing & 28 & 70 \\
machines & & \\
On the phone & 10 & 25 \\
Giving instructions & 24 & 60 \\
c. Reading & & \\
Manuals & 28 & 70 \\
Product Specification & 24 & 60 \\
Descriptive Paragraph & 28 & 70 \\
Process Paragraph & 30 & 75 \\
Text book & 32 & 80 \\
d. Writing & & 70 \\
Technical vocabularies & 28 & 57.5 \\
e-mails & 23 & 80 \\
Reports & 32 & 75 \\
Memo & 12 & 85 \\
Descriptive paragraph & 30 & \\
Process paragraph & 34 & \\
\hline
\end{tabular}

Speaking, reading, writing and listening skills are the highly needed skills of the Engineering students. Table 6 shows that the students needed the speaking skill especially for delivering oral presentation $(85 \%)$, explaining the process (75\%), describing the tools and machines $(70 \%)$, in giving instructions (60\%), and when speaking to a client on the phone (25\%). This is supported by Cullen and Pudwill (2002) who state that the ability to give a presentation is a particularly important skill for engineering students to acquire. Engineers are often asked to give technical explanation on product design or manufacturing processes.

Moreover, the reading skill is also necessary in understanding the text book $(80 \%)$, the process paragraph (75\%), descriptive paragraph $(70 \%)$, manuals $(70 \%)$ and the product specifications $(60 \%)$. Understanding and comprehending these things will help the students to write better technical vocabularies $(70 \%)$, reports $(80 \%)$, descriptive paragraph $(75 \%)$ and process paragraph $(85 \%)$. On the other hand, the students needed the listening skills mostly during the presentations $(80 \%)$, followed by during 
lectures $(70 \%)$, instructions $(67.5 \%)$, explanations of their teacher $(65 \%)$, and reports $(50 \%)$. Not being able to master the listening skill would mean difficulty passing their subjects.

\subsection{Finding from Interview \\ 4.2.2 Lecturers}

Three subject-specific lecturers from mechanical engineering department and one ESP lecturer were interviewed to have clear information about their opinion and expectation from ESP teaching in their department. The ESP lecturer stated that the most important problem the learners faced was their heterogeneity in their language proficiency, which caused serious problems for the teachers to teach and for the learners to learn successfully. According to the teacher, most available ESP books were out of date and inappropriate for ESP classes. Consequently, teacher should find or create his own materials to meet the specific needs of learners in ESP classroom. Another important point was learners' lack of motivation. Motivation plays a crucial role in ESP; however, many of the learners were not sufficiently motivated to learn English

Majority of the subject-specific lecturers said that they expected the students to be competent in technical English. As a consequence, the English learning outcomes were emphasized on the students' ability to communicate their ideas both orally and in written. Similar to the students' opinion, the subject-specific lecturers also stated that the ESP courses should focus on integrating all the four language skills although the emphasis is different.

Regarding the topics, the subject-specific lecturers said that they expected the topics given should be related to the students' expertise, which is technical field. So, the materials related to the manufacturing process, machines, tools, etc., should be mastered by the students.

\subsubsection{Employers}

The following outlines the results of interview with three employers from different companies in engineering area to get detailed information about communication skills needed by engineer in real industries. According to the three employers, English communication skills are very important in workplace. All four English language skills namely listening, speaking, reading and writing were important. Of these skills, speaking was one of the most frequently used skills. They needed this skill for everyday communication such as talking about their daily tasks and duties. In the context of their work, they had to work with foreign bosses, managers, supervisors and experts. For example, they had to express their ideas or present their solutions to technical issues; they had to report their work progress or technical problems to their foreign supervisors and managers. Reading skills were also important to know in details the products' specifications. If not, they would make mistakes in ordering spare parts and installing devices. The employers stated that the students needed listening skills to fully function their communication. That is, they had to listen to the boss or manager's instructions and understand presentations and discussions in meetings, seminars or conferences. Although writing skills were perceived as the least frequently used, they were needed for email communication and writing technical reports. The employer said that the engineers needed all four language skills to successfully carry out the communication. It indicates that engineers needed English for communication and technical English to function their work effectively.

Some employers suggested that undergraduate students should improve their English communication skills since they are very important in workplace. The communication skills should not only be given in the English instruction classroom, but also in other specific subjects.

\subsection{Instructional Materials Development}

The data from the students' questionnaires and interview have shown a number of important issues which need to be considered in developing instructional materials based on the students' communication skills needs. In developing the instructional materials, the researcher followed the steps as figured out below.

Output

Input

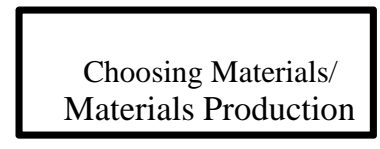

Material

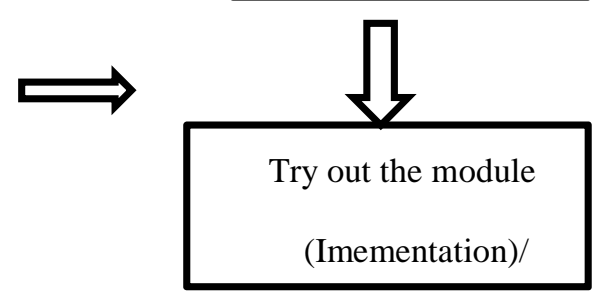

Analysis

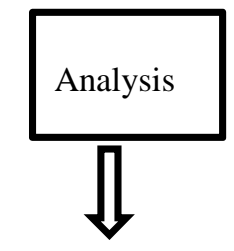

Module Revision

Figure 1. The Procedure of Developing Instructional Materials for Technical English Subject 
In ESP, method and content are based on reasons for learning, and a combination of the language skills and knowledge in the profession is observed in order to communicate effectively (Hutchinson and Waters, 1987). Thus, some of the highly needed skills based on the results of the needs assessment of this present study are addressed like: delivering oral presentation, explaining tools/machines, writing process paragraph, and reading manuals related to their technical field.

\section{CONCLUSIONS AND SUGGESTIONS}

The findings of the study reveal the need for developing English for Specific Purposes instructional materials on the target discipline, which is, English for Engineering. It is also indicated that the results are quite in agreement with the identified needs of the target group of learners. Furthermore, it is found that the participants have different expectations with respect to their needs to use the target language which shows the advantage of needs analysis concerning the identification of the learners' communication skills needs.

In conclusion, there are several important aspects from the needs analysis of questionnaire and interviews that help to identify the development of ESP instructional material for engineering students in the research site, these are: the communication skills needed for the students' future job are speaking, reading, listening and writing, and the context of the course is designed mostly for workplace situations. Based on the findings, needs analysis as one of the important components of any ESP course must be performed before designing course materials of ESP, so that the ESP course can meet the specific needs of the students.

\section{REFERENCES}

Bogdan, R.C \& Biklen, S.K. (1998). Qualitative Research for Education: An Introduction to Theory and Methods. Boston: Allyn and Bacon.

Cullen, B. \& Pudwill, L. (2002). Presentations in The Technical English Classroom. Bulletin of Nagoya Institute of Technology, 53 pp 57-64.

Dudley-Evans, T., \& Maggie, J. S. J. (1998). Developments in English for Specific Purposes: A MultiDisciplinary Approach. Cambridge: CUP.

Hutchinson, T and Waters, A. (1987). English for Specific Purposes: A Learning Centered Approach. Cambridge University Press.

Maria, P. O. (2009). "Techniques of Teaching English for Engineer". accessed on 12 February 2014 from http://www.wseas.us/eibrary/conferences/2009/budapest/DIWEB/DIWEB06. pdf $=309 \&$ VName $=$ PQD

Riabtseva, E.V. and Arestova, A.A.(2006). "Some Problems of Teaching English for Special Purposes to Students of Technical Specialities at University Level." Transactions TSTU, Retrieved on 1 September $2016 \quad$ from https://www.scribd.com/document/203399157/Some
-Problems-of-Teaching-English -for-SpecialRyabceva

Richards, J. C. (2001). Curriculum development in language teaching. Cambridge, U.K. ; New York: Cambridge University Press.

Robinson, P.C. (1980). English for Specific Purposes: The Present Position. Pergamon Press.

Stevens, B. (2005). What Communication Skills Do Employers Want? Silicon ValleyRecruiters Respond. Journal of Employment Counseling, 2005. 42(1): 2. Retrived on 2 Septembe 2016, from

http://proquest.umi.com/pqdweb?did=814722011 \&sid=1\&Fmt=4\&clientId=21690\&RQT 